\title{
2417 酸性ニッケル水溶液の水素加圧還元に関する速度論的研究
}

$\begin{array}{rrrrl}\text { 北海道大学大学院学生 } & \text { ○佐 } & \text { 藤 } & \text { 昌 } & \text { 男 } \\ \text { 北海道大学工学部助教授 } & \text { 永 } & \text { 井 } & \text { 忠 } & \text { 雄 (佂会員) } \\ \text { 北海道大学工学部教授.工博 } & \text { 田 } & \text { 中 } & \text { 時 } & \text { 昭(正会員) }\end{array}$

1. 緒

言

この研究はニッケル水溶液の水素還元の機構を検討す るために，できるだけ単純化した系を取报うことにした。 まず, 錯イオンの影響を無視し, また実験中に液の $\mathrm{pH}$ の值を一定に保つために酢酸アンモニウムでBuffer した 酢酸酸性ニッケル水溶液を使用した。市たニッケル還元 反応は界面反応なので反応の起る界面の面積変化を防ぐ ために, ニッケル板上に析出させてその速度論的な観察 を行なった。

この系に拈いて舆時間還元を行な5と, P l a t ing が 起るので容器内には, なめらかなビーカーとテフロンを 使用し, 120 分以内に実験を終了した。

\section{2. 実験方法}

実験装置は内容積 $800 \mathrm{cc}$ のステンレス製オートクレー ブでその概略は第1図に示しておる。実験溶液は特級試 楽を用いて調製し, 硫酸ニッケルに䋸衝剤として酢酸ア シモニウムを加え, 酢酸で所定の $\mathrm{pH}$ 調節した。

ニッケル板の前処理は昇温中の二ッケルの溶解や表面 の状態と密接な関係があるので重要である。ニッケル板 は $\mathrm{Ni}+\mathrm{Co} て ゙ 99.49 \%$ ののを使用し，表面をエメリ一 紙で研摩した後に混酸( 硝酸: 硫酸: 燐酸: 酢酸=3: $1: 1: 5$ ) で $90^{\circ} \mathrm{C}, 15$ 秒間化学研摩して乾燥, 秤量 した。

所定の溶液を入れたオートクレーブにニッケル板を吊 るし, 真空脱酸を行なった後, アルゴンを加死し所定温 度に昇温してから水素を加生し，このときを還元開始時 間とする。サンプリングは定期的に行ない, シメチルグ リオキシム法によって液中のニッケル濃度を決定した。 䢜元終了後, オートクレーブを冷却用水槽につけて急冷 し, ニッケル板の重量を測定する。Plating 防止の意 味を含めて実験終了後オートクレーブ内（ビーカ一, サ ンプリングチューブ，スターラー等）を研摩液と同じ混 酸で毎回洗浄した。

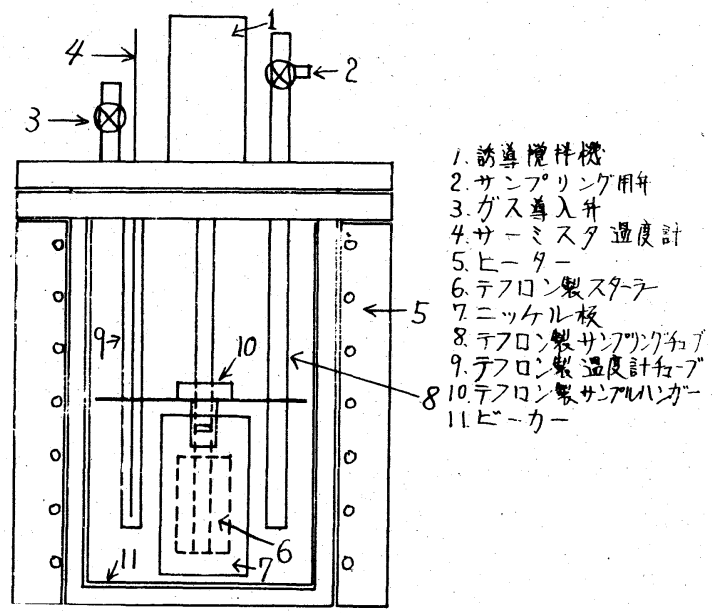

第1図 装置概略図

\section{3. 実 験 結 果}

ニッケル板上へのニッケルの析出は皮応の初期から表 裏共に均一に起っていることが観察され, かつ析出量が 反応初期飞直線的に増加することからニッケル板上での 核発生の問題は無視できる。析出速度は還元量一時間曲 線に打㘬配より計算した。

摫拌の析出速度に対する影響は $60 \mathrm{rpm}$ から $1040 \mathrm{rpm}$ まで摫拌速度を变化させたがその影響を認められなかっ た。このことより以後の実験はすべて $610 \mathrm{rpm} て ゙$ て行なっ た。また析出速度はニッケル板表面積に比例した。

第 2 図はニッケル初期濃度 $\left[\mathrm{Ni} \mathrm{Ni}_{0}\right.$ の析出速度に和よ゙ す影響を示すもので濃度に対する反応次数は 1 次にはな らず分数次数になる。

第 3 図は水素分圧 $\left\{P_{\mathrm{H}_{2}}\right\rfloor$ の影響を示して打り, 析出速 度は水素分圧の平方根に比例している。このことから吸 着平衡がニッケル板上で成立していると考えると水素は 解離吸着しているものと考光られる。

$\mathrm{pH}$ が 4 以下になると析出速度は急激に減少する。こ れは $\mathrm{E}-\mathrm{pH}$ 図からも説明できる。

アレニウスプロットより活性化土ネルギ一を求める と $27.5 \mathrm{k} \mathrm{col} / \mathrm{mol}$ となり拡散が律速とは考元られ

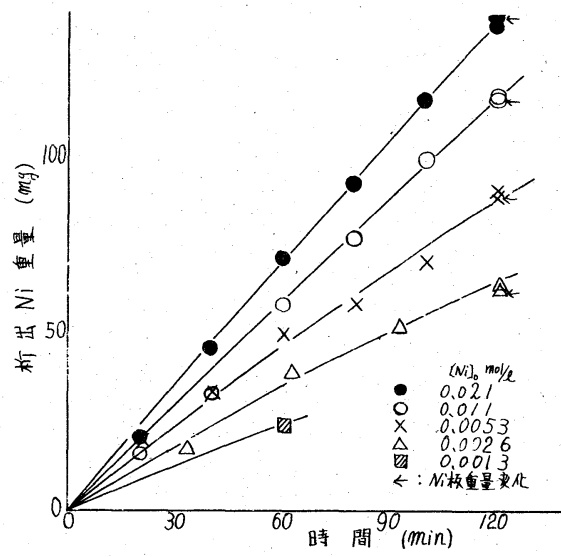

$T: 185^{\circ} \mathrm{C}, \mathrm{pH}: 4.3, \mathrm{P}_{\mathrm{H}_{2}}: 22 \mathrm{~kg} / \mathrm{cm}^{2}$, $\mathrm{Ni}$ 表面積 : $24 \mathrm{~cm}^{2}$

第2図ニッケル初期濃度の析出速度に招よぼす影響

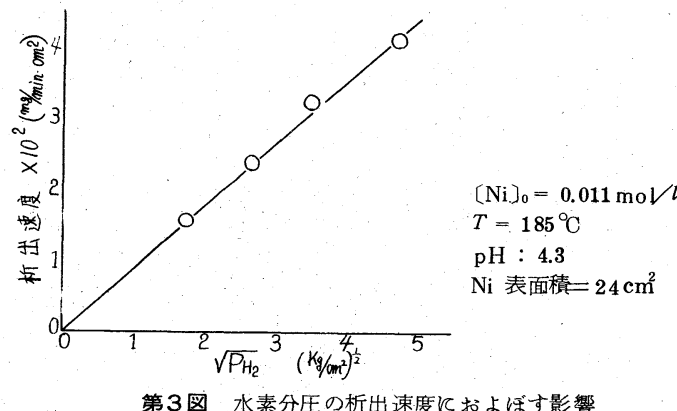

第3図 水素分圧の析出速度に招よぼす影響 
ない。

液分析より求めたニッケル析出量はニッケル板の重量 变化量と良く一致し, Plating がこの実験時間内では ほとんど起っていないことを示している(第2罒)。ガ ラスやテフロンの表面状態が悪いため還元実験のあいだ 飞Platingが起った場合には第 4 図のよ5な析出量一 時間曲線が得られ, 反応初期の曲線を延長すると還元終 了時に打けるニッケル板の重量変化から求めた析出量が のってくることから液分析から得られた曲線との差が Plating した量と考えることができる。

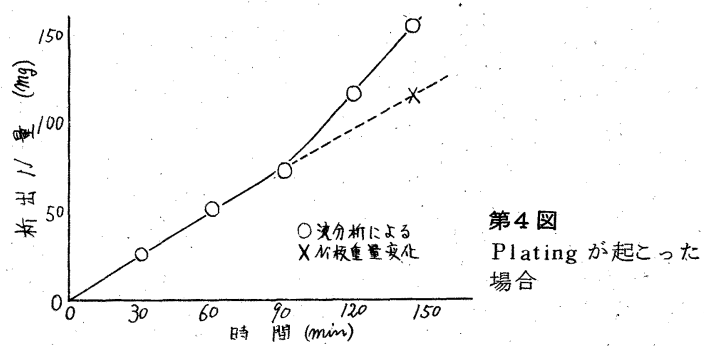

\section{Nitrofluor 化学によるイルメナイト中の Tiの回収に関する研究}

\begin{tabular}{|c|c|c|c|c|}
\hline 東北大学選鉱製鍊研究所助教授 - 工博 & 木 & 越 & 旭 & 一(正会員) \\
\hline 東北大学選鉱製鈛研究所助手 & 天 & 川 & & 淳 \\
\hline 東北大学選鉱製錬研究所 & 4 & 村 & 由 & 子 \\
\hline
\end{tabular}

\section{1.緒言}

無水の弗化水素に三酸化窒素, 過酸化咥素, 弗化二卜 ロシルあるいは塩化ニトロシルなどを添加すると，それ ぞれの成分より蒸気压の低い液体が得られる。またそれ

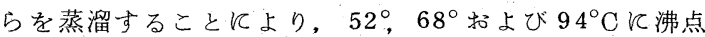
を有する共沸混合物が得られる。これらの非水溶液 (以 後溶剂々呼ぶ) は, 金属の種類によって溶剂飞可溶な錯 弗化物か，あるいは不溶の単純弗化物を作る性質がある。 これらの化学をNitrofluor 化学と総称しているが, これを, イルメナイト中の $\mathrm{T}$ i の回収に応用した結果に ついて報告する。

\section{2. 実 験 試 料}

セイロン島産イルメナイトの 32 ～ 100 mesh 部分を試 料として使用した。品位は $\mathrm{TiO}_{2} 52.63 \%, \mathrm{FeO} 29.18 \%$, $\mathrm{Fe}_{2} \mathrm{O}_{3} 17.62 \%, \mathrm{SiO}_{2} 1.90 \%$ で, その他飞極く微量 の $\mathrm{Mn}$ 扣よび Moを含む。

これを処理する溶剤としては, 無水弗化水素 (Matheson: 製， $99.9 \%)$ K. $20 \mathrm{M} \%$ の無水過酸化窒素( $\mathrm{Ma}$ theson 製， $99.5 \%$ ) を加え，これを1気圧の下で蒸 溜して得られる $52{ }^{\circ} \mathrm{C}$ 定沸点を有する溜分を使用した。

\section{3. 実験結果および考察}

\section{$3 \cdot 1$ 溶剤による抽出}

イルメナイトに溶剂を注ぎ, これを $50^{\circ} \mathrm{C}$ の一定温度
に保持した後, 㱥㵠㾀心分離し, 抽出液を分析して $\mathrm{Ti}$ 扣よびFeの抽出率を求め, これを第 1 図に示した。 1 時間の反応では杗だ末反応の部分が残っているが，2 時間では完全に分解する。 $\mathrm{Ti}$ の抽出率は 2 時間で約 92 \%に達し、その後わずかに増加して96時間では $98 \%$ 抽出される。 $\mathrm{Ti}$ 《 $\left(\mathrm{NO}_{2}\right) \mathrm{TiF}_{6}$ の形で抽出されるものと 考えられる。 Feは2時間では約 50 \% が抽出されるが, その後減少し，96 時間での抽出率は約 4 \%である。 $\mathrm{Fe}$ は溶剤によって一部は $\mathrm{FeF}_{3}$ になるが，他は $\mathrm{NOFeF}_{4}$ の形で一旦溶剂に抽出され，その後過剩の溶剤が蒸発し て飽和て達すると

$\mathrm{NOFeF}_{4} \rightarrow \mathrm{FeF}_{3}+\mathrm{NOF}$

によって溶剂に不溶性の $\mathrm{FeF}_{3}$ が增加するために, $\mathrm{Fe} の$ 抽出率が減少するものと考光られる。

以上の上うに, イルメナイトは溶剤によって容易に分 解し，これを長時間保持することにより， Ti なりよく分離されるが，充分とはいえないので，次有 機溶剂による再抽出招よび揮発精鍊について検討した。

\section{3・2 有機溶剤による再抽出}

イルメナイトを $50^{\circ} \mathrm{C} に$ おいて溶剤で約 2 時間処理し 遠心分離して得た溶液を $100^{\circ} \mathrm{C}$ 亿打いて減圧乾燥して 試料とした。その組成は $\mathrm{Ti} 26.72 \%, \mathrm{Fe} 15.16 \%$, F $57.51 \%$ で, $\mathrm{TiF}_{4}$ と, $\mathrm{FeF}_{3}$ との混合物と考えら れる。

この試料を $20^{\circ} \mathrm{C}$ で有機溶剂で抽出した結果，第 1 表 飞示すょうにかなり有効なものもあるが，決定的な効果

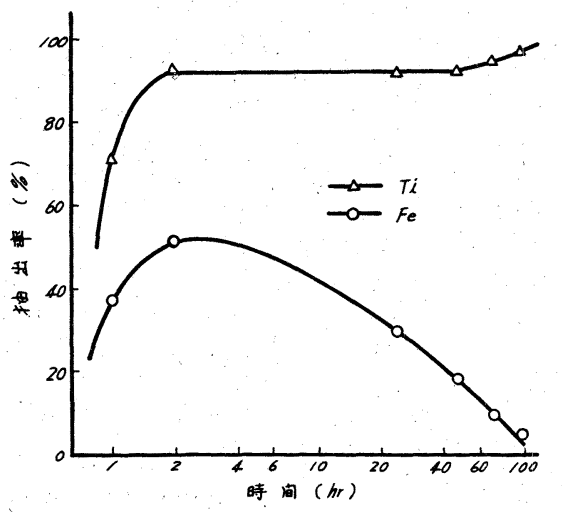

$412<252>$

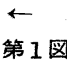

抽出率に招よぽす 時間の影響

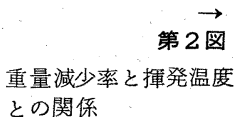
との関係

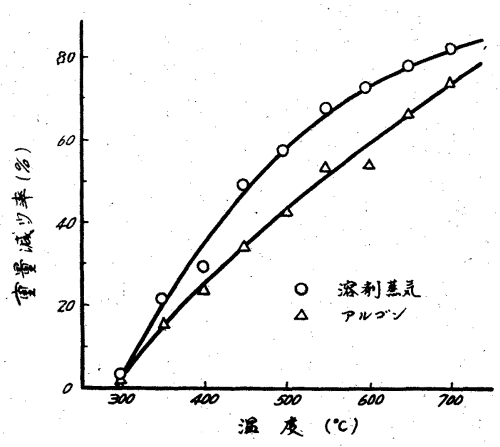

日本鉱業会誌 